\title{
Rules arrive under a cloud
}

\section{Washington}

SIX years after Congress passed controversial legislation requiring strict new rules for handling laboratory animals, the US government has finally finished those rules, if not the controversy.

Last week, the US Department of Agriculture (USDA) released an 85,000-word final regulation for the treatment of research dogs, cats and non-human primates. The new rules follow two previously published sets of regulations on smaller animals and finish what has essentially been a three-part rewriting of the entire Animal Welfare Act.

Years of debate over the need for stronger regulations and the changes that are appropriate led Congress in 1985 to pass amendments to the Act. But legislators left unclear exactly how they wanted USDA to rewrite the rules. So the past six years have seen a pitched battle between researchers and animal-welfare activists to determine the final form of the regulations, a struggle the research community now seems to have won.

The new regulations set specific standards for such concrete matters as cage sizes but leave the particulars of animal exercise and psychological health largely in the hands of the experimenters - an arrangement that researchers applaud. Animal-welfare activists, however, who had originally fought for the regulations and then sued to speed their release, attacked the rules as a "great leap backwards" and threatened further law-suits to force USDA to set more rigid standards.

The disagreement centres around 'engineering' versus 'performance-based' standards. In matters such as cage sizes and environmental conditions such as temperature and humidity, the new regulations essentially codify the existing housing and treatment guidelines of the National Institutes of Health (NIH) by setting minimum dimensions and enclosure volumes. But in matters of animal exercise and 'lifestyle', USDA has adopted performance-based standards.

Agency inspectors will observe the animals to determine if they act in a healthy and well adjusted way, rather than to prescribe exact minimum procedures and cage configurations. Researchers will have to document that the procedures they use have been shown to encourage healthy animal behaviour. Should a USDA inspector find evidence of psychological abnormality in a primate, the burden of proof will be on the institution to show that the problem is not a result of inappropriate housing conditions.

Even in the case of enclosure dimensions - normally a strictly engineering matter - USDA will now permit some performance-based flexibility. The new rules permit 'innovative caging': housing that may not exactly fit the cage size formula, but nevertheless allows for healthy animal behaviour.

Although the scientific community has historically opposed more regulation of animal facilities, research advocates have praised the new rules. By adopting the NIH guidelines, USDA has increased minimum cage sizes in many cases. But most research facilities, as recipients of NIH grants, had already adopted the more stringent standards, says Barbara Rich of the National Association for Biomedical Research. "For most institutions, probably the majority, the new rules will mean no change", she says.

With regret, animal-welfare activists agree. Congress had intended vast reform when it passed the amendments to the Animal Welfare Act in 1985, they argue. But if research facilities find that the new regulations require little change, animal welfare can hardly be expected to substantially improve as a result. Performancebased rules, says William Cotreau of the Animal Welfare Institute (AWI), "are like no rules at all. They're suggestions."

The San Francisco-based Animal Legal Defense Fund (ALDF) intends to file a suit charging USDA with violating congressional intent, but even activists admit that the congressional language on the amendments is unclear. And, as USDA points out, Congress's 1991 agriculture appropriations bill calls for "performance-based standards . . . when such standards would not interfere with the establishment of a minimal level of care or the enforceability of the Act".
"Overall, we believe we produced a practical and enforceable blend of performance and engineering standards", said James Glosser, administrator of USDA's Animal and Plant Health Inspection Service, in a prepared statement last week. "We have made room for variations in the way individual animals behave and for differences in the way they are used and housed. We also have provided flexibility in complying with the regulations by offering more than one option for achieving certain standards."

USDA estimates that compliance with the new rules will cost US researchers $\$ 537$ million. A stricter version of the rules more in line with the demands of the animal-welfare activists would have cost research facilities $\$ 1,750$ million, or more than three times as much, USDA calculated. The shift to performance-based standards was in large part due to what USDA considered an unreasonable expense to the research community.

AWI, however, counters with its own figures. An analysis of the USDA calculations released recently by AWI claims that accounting errors and erroneous assumptions overstate the cost of the more strict rules by over $\$ 1,000$ million. With the new accounting, AWI argues that the strict rules would cost little more than the regulations USDA actually released, while significantly improving the lot of research animals. Should ALDF file suit as expected, it will probably raise that issue as well.

But unless a federal judge rules against USDA - an outcome that would be rare in such a case - the new rules will stand and the battle that has clouded the Animal Welfare Act for six years will be over.

Christopher Anderson

\section{British scientists hit back}

\section{London}

AN open letter to the British Prime Minister, John Major, signed by 72 distinguished expatriate British scientists, emphasizes the critical condition of British science and demands government action to reverse the trend. The letter, organized by the California-based pressure group British Scientists Abroad (BSA), comes almost exactly a year after a BSA petition with 1,647 expatriate signatories was snubbed by the government.

That earlier petition (see Nature 343, $499 ; 1990$ ) had been organized in response to government statements that the socalled 'brain drain' did not exist, because researchers from abroad came to Britain to fill the gaps left by those leaving. The petition called on the government to increase research support in line with civil research expenditure in other major industrialized nations, and to institute tax incentives for industrial laboratories that publish their research.

Although 24 of the signatories of the original petition were fellows of the Royal Society and more than a hundred were heads of department, the government dismissed it as unimportant on the grounds that most of the signatories held junior positions. This excuse may be undermined by the list of signatories of the new open letter, which reads like a roll-call of illustrious innovation. They are all fellows of either the Royal Society or the Fellowship of Engineering, with addresses predominantly in the United States.

The open letter restates the message in last year's petition, adding that "unless the government acts to halt the decline in research, we fear that Britain will become a minor player in technological development. The consequent economic and social damage would be severe." Henry Gee 